WHC-EP-0734

\title{
Tank 241-C-103 Headspace Flammability
}

\author{
J. L. Huckaby \\ Date Published \\ January 1994
}

Prepared for the U.S. Department of Energy Office of Environmental Restoration and Waste Management

\footnotetext{
(W) Westinghouse P.O. Box 1970

Hanford Company Richland, Washington 99352

Hanford Operations and Engineering Contractor for the

U.S. Department of Energy under Contract DE.AC06-87RL10930
} 


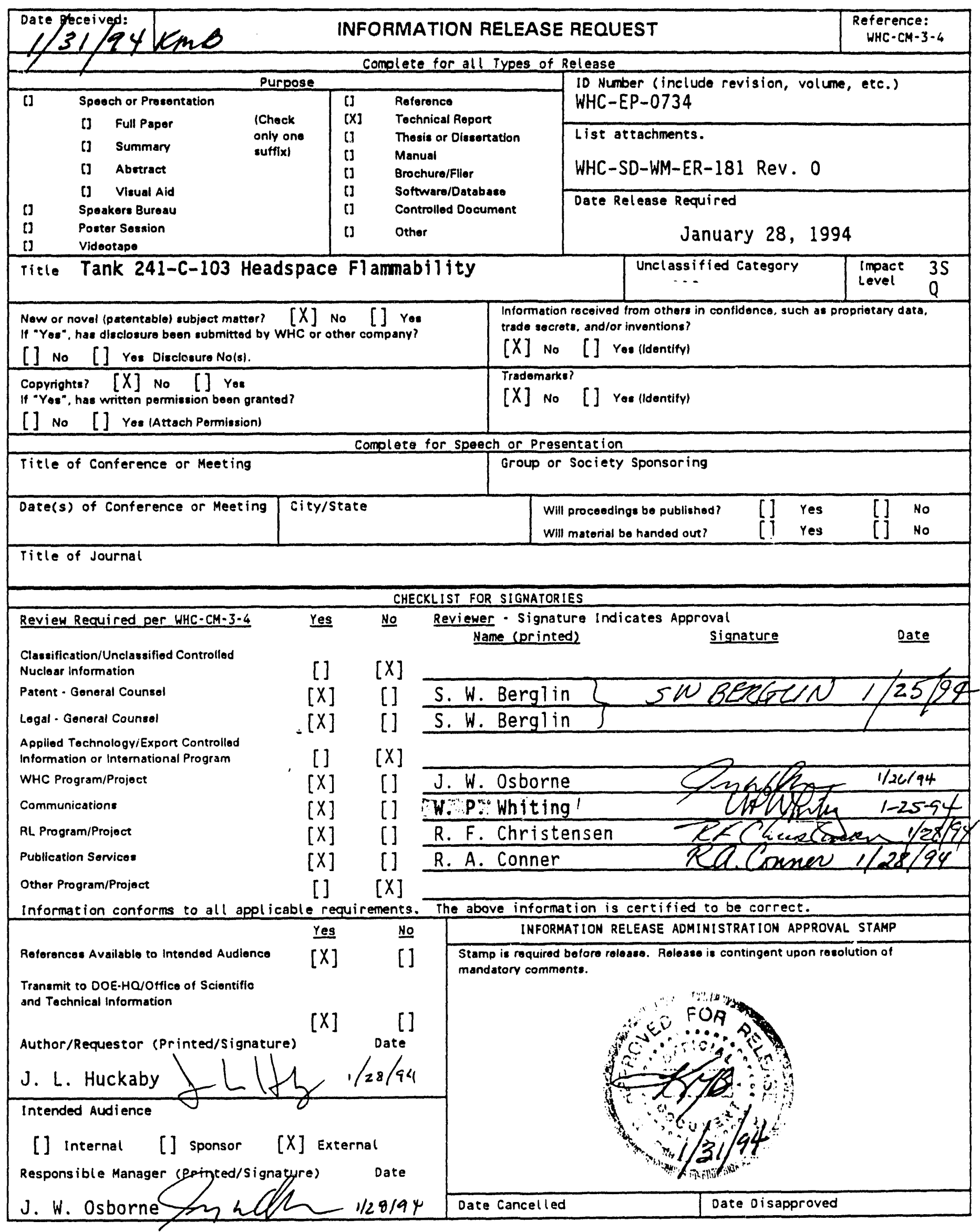




\section{CONTENTS}

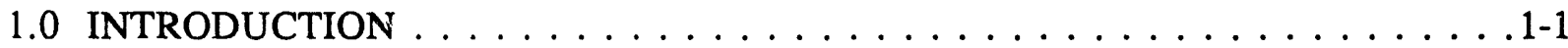

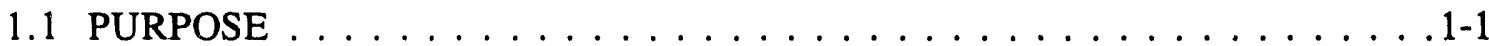

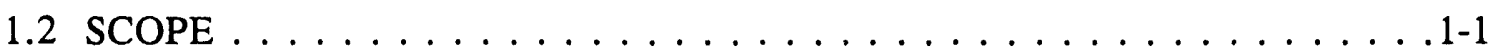

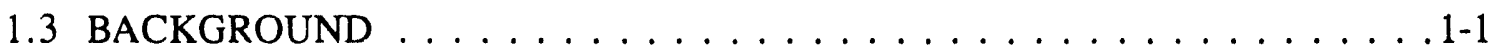

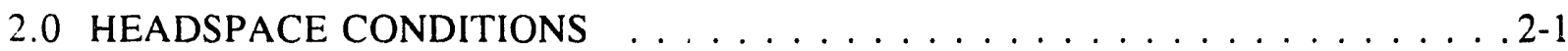

2.1 TANK DESCRIPTION $\ldots \ldots \ldots \ldots \ldots \ldots \ldots \ldots \ldots \ldots \ldots \ldots \ldots$

2.2 HEADSPACE CONVECTION $\ldots \ldots \ldots \ldots \ldots \ldots \ldots \ldots \ldots \ldots \ldots \ldots$

2.3 HEADSPACE BREATHING $\ldots \ldots \ldots \ldots \ldots \ldots \ldots \ldots \ldots \ldots . \ldots \ldots$

2.4 HEADSPACE TEMPERATURE $\ldots \ldots \ldots \ldots \ldots \ldots \ldots \ldots \ldots . \ldots \ldots$

3.0 FLAMMABLE HEADSPACE CONSTITUENTS

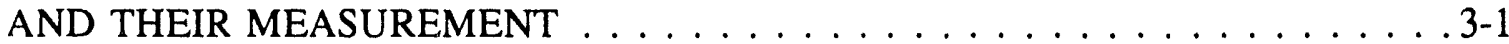

3.1 COMBUSTIBLE GAS METERS $\ldots \ldots \ldots \ldots \ldots \ldots \ldots \ldots \ldots$

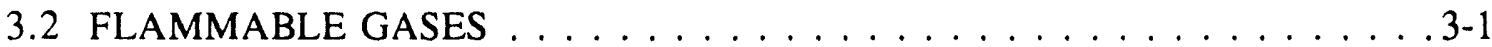

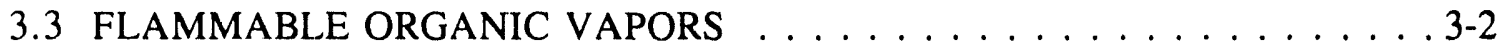

3.4 FLAMMABLE ORGANIC LIQUID AEROSOL $\ldots \ldots \ldots \ldots$. . . . . . . . .

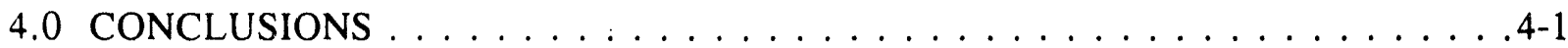

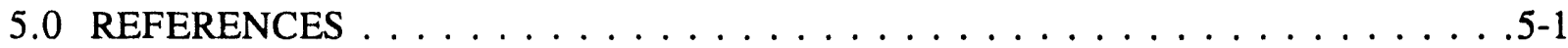

ATTACHMENT A ........................ A-1 


\section{LIST OF FIGURES}

2-1 Tank 241-C-103 Riser Locations . . . . . . . . . . . . . . . . . . . 2-2

2-2 The Tank 241-C-101, 241-C-102, and 241-C-103 Cascade . . . . . . . . . . 2-3

\section{LIST OF TABLES}

3-1. NPH Concentrations Measured in OVS Traps from Tank 241-C-103. . . . . . . . 3-3

3-2. Principle Constituents of Organic Liquid Waste in Tank 241-C-103 . . . . . . . 3-5

\section{LIST OF ATTACHMENTS}

A An Engineering Assessment of the Aerosol and Vapor Flammability in 241-C-103 A-1

\section{LIST OF ACRONYMS}

$\begin{array}{ll}\text { CGMs } & \text { Combustible gas meters } \\ \text { FIC } & \text { Food Industries Company } \\ \text { HEPA } & \text { High-efficiency particulate air [filter] } \\ \text { LFL } & \text { Lower flammability limit } \\ \text { NPH } & \text { Normal paraffinic hydrocarbons } \\ \text { OSHA } & \text { Occupational Safety and Health Administration } \\ \text { OVS } & \text { OSHA versatile sampler } \\ \text { PUREX } & \text { Plutonium-uranium extraction } \\ \text { RTDs } & \text { Resistance temperature devices } \\ \text { TBP } & \text { Tributyl phosphate }\end{array}$




\subsection{INTRODUCTION}

\subsection{PURPOSE}

Information regarding flammable vapors, gases, and aerosols is presented for the purpose of resolving the tank 241-C-103 headspace flammability issue. Analyses of recent vapor and liquid samples, as well as visual inspections of the tank headspace, are discussed in the context of tank dynamics.

\subsection{SCOPE}

This document is restricted to issues regarding L._flammability of gases, vapors, and an aerosol that may exist in the headspace of tank 241-C-103. While discussing certain information about the organic liquid present in tank 241-C-103, this document addresses neither the potential for, nor consequences of, a pool fire involving this organic liquid; they will be discussed in a separate report.

\subsection{BACKGROUND}

Concern that the headspace of tank 241-C-103 may contain a flammable mixture of organic vapors and an aerosol of combustible organic liquid droplets arises from the presence of a layer of organic liquid in the tank. This organic liquid is believed to have originated in the plutonium-uranium extraction (PUREX) process, having been stored initially in tank 241-C-102 and apparently transferred to tank 241-C-103 in 1975 (Carothers 1988). Analyses of samples of the organic liquid collected in 1991 and 1993 indicate that the primary constituents are tributyl phosphate (TBP) and several semivolatile hydrocarbons (Prentice 1991, Pool et al. 1994). This is consistent with the premise that the organic waste came from the PUREX process, because the PUREX process used a solution of TBP in a diluent composed of the $n-\mathrm{C}_{11} \mathrm{H}_{24}$ to $n-\mathrm{C}_{15} \mathrm{H}_{32}$ normal paraffinic hydrocarbons (NPH).

At the temperature of the waste surface, the vapor pressure of the PUREX process TBP-NPH solution is known to be far too low to support flame propagation (van Tuyl 1983; also see Attachment A). However, if a very dense aerosol of organic liquid droplets were present in the headspace, a flammable condition could exist. The possibility of such an aerosol was supported by reports that the headspace was foggy, and by data from a developmental vapor sampling event in 1989 (Ulbricht 1991, Trent 1990) that was shown to have been experimentally flawed (Story 1992).

A methodology for determining the flammability of the tank $241-\mathrm{C}-103$ headspace was developed between September and December 1992 by a team of scientists and engineers working for the Tank Vapor Issue Resolution Program. This methodology involves three steps. The first step, performed in November 1993, was an initial evaluation of the 
concentrations of flammable permanent gases present. The second step, performed in December 1993, was to determine the total concentration of NPH, both in the aerosol and vapor phases, in the tank 241-C-103 headspace. For this, filtered sorbent traps were inserted directly into the headspace to trap the NPH in situ.

These first two sampling events provided direct evidence that the fuel content of the headspace is well below levels of concern. The November sampling was accomplished by non-intrusive means, drawing tank gases and vapors directly from access ports on two of the tank risers. This sampling method limits the validity of the sampling with respect to condensible and condensate-soluble vapors, but affords a reasonably good analysis of permanent gases such as hydrogen and methane. These gases were determined to be at acceptable levels. The initial sampling for NPH, performed in December, revealed that the current NPH concentration in the headspace is far below levels of concern for flammability. The December sampling event also established that no aerosol was visibly present in the headspace.

The third step to resolve the tank 241-C-103 headspace flammability issue, begun in January 1994 but planned to continue throughout the year, requires that representative samples be collected from the headspace for determining the concentrations of flammable gases and volatile organic species, as well as further analyses of semivolatiles such as NPH. The sampling events are planned to characterize the toxicologically significant species in tank 241-C-103, but will also serve to ensure seasonal variations do not significantly affect the conclusions of this report. 


\subsection{HEADSPACE CONDITIONS}

\subsection{TANK DESCRIPTION}

Tank 241-C-103 is a 530-kgal, high-level nuclear waste storage tank. Constructed in 1943-1944, it has a single, 22.9-m (75-ft)-diameter mild steel liner supported by reinforced concrete and a reinforced concrete dome. The dome supports 11 steel pipe risers through which the tank contents may be accessed. Figure 2-1 depicts the arrangement and schedule of tank 241-C-103 risers, and the locations of the 3 concrete access pits. As shown in Figure 2-2, tank $241-\mathrm{C}-103$ is also directly connected to tank $241-\mathrm{C}-102$ by a buried, $7.6-\mathrm{m}$ (25-ft)-long, 7.6-cm (3-in.)-diameter cascade line. When tank 241-C-102 was full, the cascade line allowed the overflow of liquid to tank 241-C-103. A similar cascade line connects tanks 241-C-101 and 241-C-102.

Currently, tank 241-C-103 contains approximately $195 \mathrm{kgal}$ of sludge and aqueous liquid waste (Hanlon 1994), as calculated from a measured waste depth of $168 \mathrm{~cm}$ (66 in.) In addition, tank $241-\mathrm{C}-103$ has a floating layer of organic liquid waste (immiscible in the aqueous waste) determined to be between 3.8 and $5 \mathrm{~cm}$ (1.5 and 2.0 in.) thick in December 1993. A Food Industries Company (FIC) automatic level gauge, mounted on riser \#8, is used to determine the aqueous waste surface, by conductivity, on a weekly basis.

The relative stability of the waste surface level in tank $241-\mathrm{C}-103$ is an indication that the tank does not undergo periodic venting of gases from the stored waste. Burke (1991) has charted the surface level data from tank 241-C-103 between 1980 and 1991 . The data indicate a decrease in the surface level of the tank of about $4 \mathrm{~cm}(1.6 \mathrm{in}$.) over the 11 -year period, which Burke attributes to the evaporation of water. Deviations from the running baseline level are indicated to be on the order of tenths of an inch, or at about the resolution of the level gal.ge itself. Though the level gauge data is not recorded continuously, there is no evidence tank $241-\mathrm{C}-103$ is undergoing episodic gas release events.

\subsection{HEADSPACE CONVECTION}

The headspace of tank $241-\mathrm{C}-103$ is expected to be mixed by convective air currents. Radioactive decay occurring within the waste generates heat that is transferred in all directions from the tank. The waste surface is thus warmer than the concrete dome, resulting in the upward convection of air warmed by the waste surface and downward convection of air cooled by the concrete dome. According to a model developed by S. A. Wood (1992) to describe the headspace of a similar situation in tank 241-C-109, warm air rises in the central region of the tank, flows outward along the dome, and falls at the tank wall.

Evidence of headspace mixing was recently obtained during the December 1993 vapor sampling event in tank 241-C-103. Resistance temperature devices (RTDs) located on the 
Figure 2-1. Tank 241-C-103 Riser Locations.

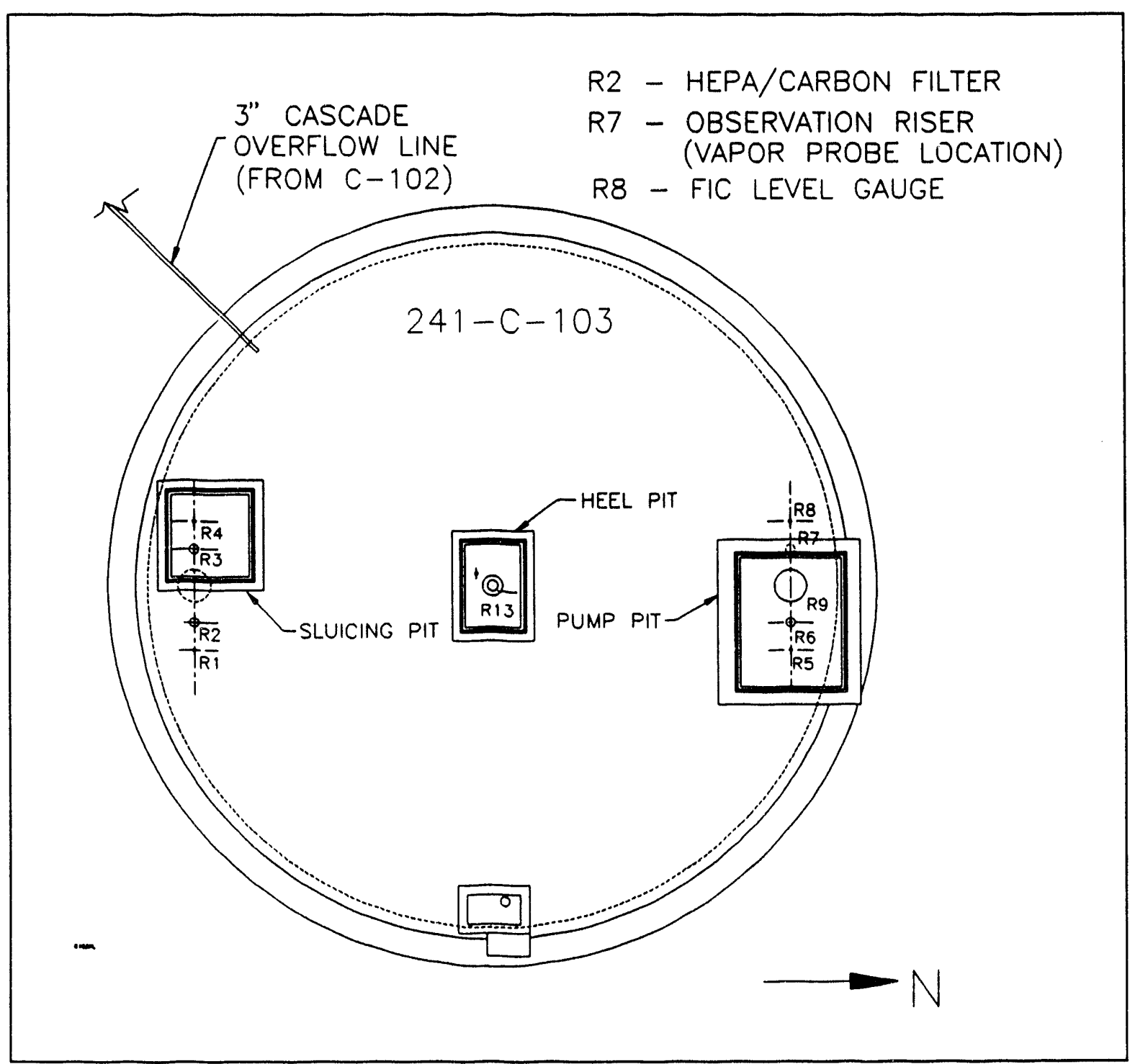


Figure 2-2. The Tank 241-C-101, 241-C-102, and 241-C-103 Cascade.

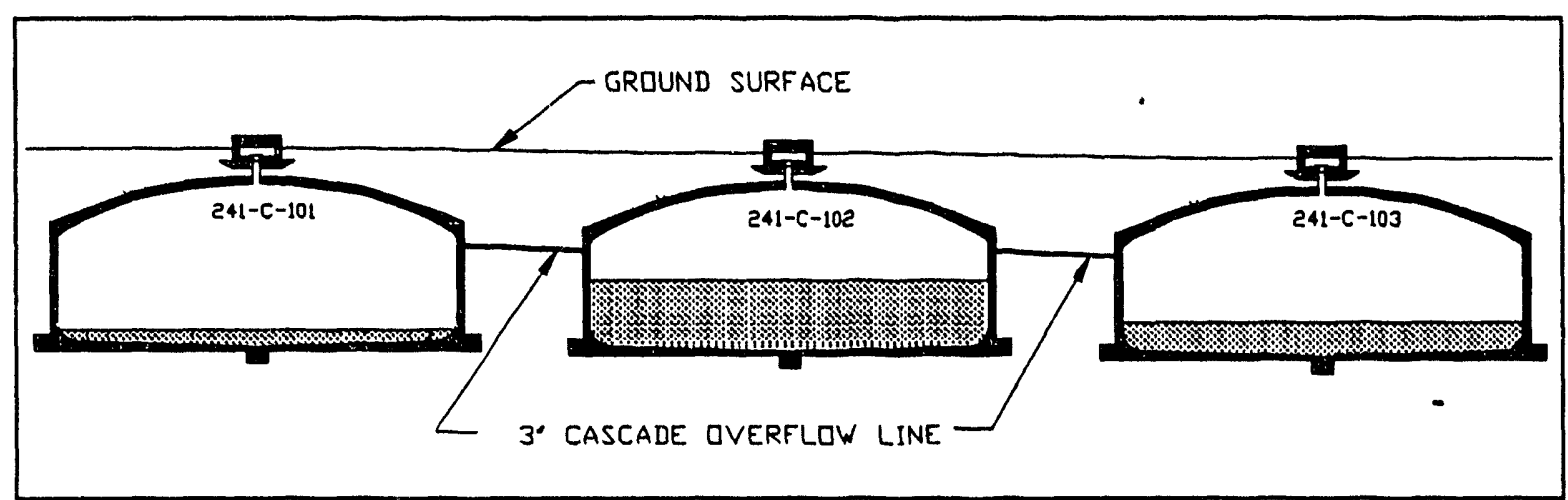

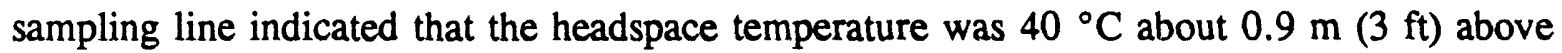
the surface and also at a point $3.05 \mathrm{~m}$ (10 ft) higher. This is consistent with the expectation that if convection is significant, the steepest temperature gradients would be found in the relatively stagnant regions very near the surface and near the dome, and that a relatively small temperature gradient would exist between those regions.

Visual inspection through the observation riser during the December sampling event was performed shortly after the cover flange was removed, and indicated that a low particle number density, non-uniform aerosol did exist in the riser itself. The thermal gradient between the cool riser cover flange and the tank headspace itself was apparently large enough to promote convection within the 4.9-m (16-ft)-long, 30.5-cm (12-in.)-diameter riser, producing an aerosol as warm, moist tank air contacted air cooled by the riser flange. This observation suggests that even air within the risers is not subject to stagnation as long as the top of the riser is occasionally much cooler than the headspace.

\subsection{HEADSPACE BREATHING}

Pressure differences between the atmosphere and tanks 241-C-101, 241-C-102, and 241-C-103 due to generation of gases and vapors in the tanks and to barometric changes, are relieved by passive ventilation. Each tank has a dedicated breather riser that is equipped with a high-efficiency particulate air (HEPA) filter to limit release of radioactive particulates from the tank. Additionally, small openings and cracks in the pit covers and unsealed risers allow some air to pass unfiltered between the tanks and the atmosphere. ${ }^{1}$ Currently, valves

'The potential spread of radioactive contamination via these pathways is monitored by area air monitors, and is being addressed by the EPA (Pelletier 1993). 
at the HEPA filters of tanks $241-\mathrm{C}-101$ and $241-\mathrm{C}-103$ are shut, so that all 3 tanks in the cascade breathe through tank 241-C-102 and its HEPA filter. This has been the ventilation configuration since March 1993.

Changes in the barometric pressure cause passively ventilated storage tanks at the Hanford Site to exchange an average of 0.46 percent of the air in their headspace with the atmosphere per day ${ }^{2}$. Given the headspace volume of tank $241-\mathrm{C}-103$ is about $2,550 \mathrm{~m}^{3}$ $\left(90,000 \mathrm{ft}^{3}\right)$, barometric pressure changes would cause about $11.6 \mathrm{~m}^{3}\left(410 \mathrm{ft}^{3}\right)$ of air to be exchanged between the tank and the atmosphere each day. During an average day, the barometric pressure rises for approximately 8 hours, falls for approximately 8 hours, and shows negligible changes during the remaining 8 hours (Crippen 1993).

Dry instrument air is also introduced at a rate of 1.4 to $1.7 \mathrm{~m}^{3} / \mathrm{hr}\left(50\right.$ to $60 \mathrm{ft}^{3} / \mathrm{hr}$ ) at the FIC level gauge housing of tanks 241-C-102 and 241-C-103 to prevent condensation of moisture in the housing ${ }^{3}$. This flow rate of instrument air results in about 1.3 to 1.7 percent of the headspace being purged each day. The typical diumal barometric cycle is such that some air would still be drawn into tank 241-C-103 from tank 241-C-102 and from unsealed risers and pit covers, but only during the steepest barometric pressure increases. In summary, the average total daily inflow of fresh air is estimated to be no more than about 2 percent of the headspace volume.

\subsection{HEADSPACE TEMPERATURE}

The waste and headspace temperatures are monitored on a weekly basis. Three thermocouples are located in the waste; the lowest thermocouple is essentially on the tank

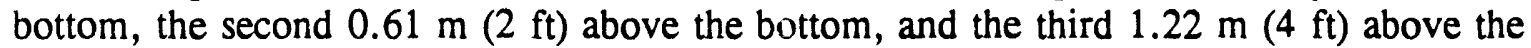
bottom. The sole thermocouple in the headspace is approximately $2.79 \mathrm{~m}(9 \mathrm{ft} 2 \mathrm{in}$.) above the waste surface.

The thermocouples in tank 241-C-103 indicate the waste and headspace temperatures fluctuate with the seasons, and are generally hottest in October and November, and coolest in April and May. These seasonal changes are related to ground temperatures (Crowe et al. 1993). Given the relatively small fraction of headspace gases exchanged per day discussed in Section 2.3, effects on the temperature of the headspace by the diurnal inflow of cold or hot

${ }^{2}$ This value was calculated in the manner of Garfield 1975 , using hourly barometric readings for 1988, 1989, 1990, and 1991 from Crippen 1993, and assuming negligible resistance to the exchange of air.

${ }^{3}$ The rotameters on tanks $241-\mathrm{C}-102$ and $241-\mathrm{C}-103$ measuring flow of instrument air were monitored on several occasions during November and December 1993. Air flow was observed to fluctuate in the stated range, apparently due to minor supply pressure fluctuations. 
ambient air appear to be negligible. The headspace temperature of tank $241-\mathrm{C}-103$ has been observed to be as high as $44^{\circ} \mathrm{C}$ and as low as $37^{\circ} \mathrm{C}$ in the last 2 years.

Gradual reduction of the heat-generating radioactive materials in the waste tanks by radioactive decay results in successively less heat generation and cooler waste temperatures. Recent thermocouple data indicate that tank $241-\mathrm{C}-103$ is cooling at a rate of about $0.6^{\circ} \mathrm{C}$ per year (Crowe et al. 1993). The radiolytic and chemical production of flammable gases and vapors by first order reaction kinetics should also decline. Furthermore, as the tank cools, the vapor pressure of the organic liquid in the tank will also decrease. 
This page intentionally left blank. 


\subsection{FLAMMABLE HEADSPACE CONSTITUENTS AND THEIR MEASUREMENT}

The flammability of a mixture of gases and vapors cepends on the concentrations of fuel and an oxidizer. In the headspace of tank 241-C-103 the only creditable oxidizer is oxygen, which is present in roughly the same concentration as it is in normal air. Fuels known to be present in the headspace of the tank include inorganic gases such as ammonia and hydrogen, organic gases such as methane, volatile organic vapors such as acetone and butanol, and semivolatile organic vapors such as NPH and TBP.

\subsection{COMBUSTIBLE GAS METERS}

Combustible gas meters (CGMs) are used routinely by health and safety technicians at the Hanford Site to assess the flammability of waste tank gases and vapors prior to intrusive tank work. CGMs provide a digital readout of the fuel content of an air sample as a percentage of the lowest concentration of fuel which will support flame propagation, the lower flammability limit (LFL). When calibrated with pentane, as is typical, the CGMs tend to overestimate the contributions of such combustible gases as hydrogen and methane to the flammability of a sample (ISC 1991). Conversely, the CGMs used tend to underestimate the fuel value of high molecular weight organic vapors. An important example of the latter is $\mathrm{NPH}$, for which a pentane-calibrated CGM may underestimate the fuel value by as much as a factor of 3 (Estey 1992).

Monitoring of the November and December sampling events was performed using an Industrial Scientific Corporation model TMX-410 meter. It was calibrated with pentane each morning prior to use, according to a standard single-point calibration method per the manufacturer's specifications. According to the CGM, total fuel content was determined to be 0 to 7 percent of the LFL from a total of 11 readings at risers $\# 2, \# 7$, and $\# 8$ (WHC 1993). Three readings of the headspace, taken via a tube lowered to the bottom of riser $\# 7$ on December 2, 14, and 15, were 4,7 , and 7 percent of the LFL, respectively. A similar reading of the headspace, taken just prior to sample probe installation in riser $\# 7$ on January 21,1994 , was 6 percent of the LFL.

\subsection{FLAMMABLE GASES}

Flammable gases such as hydrogen, methane, and ammonia are known to be produced by radiolytic and chemical reactions within the high-level waste. As such, their current levels reflect a dynamic balance between their generation rates and such depletion mechanisms as tank breathing.

Hydrogen and methane have been detected in tank 241-C-103. Air samples collected in November from the FIC riser $(\# 8)$ and the HEPA filter riser $(\# 2)$ were analyzed and 
determined to contain between 590 and 874 parts per million by volume (ppmv) hydrogen, and between 13.2 and 17.7 ppmv of methane (Einfeld 1994). Given that the LFL for hydrogen is 4.0 percent by volume, and 5.0 percent by volume for methane (Zabetakis 1965), these air samples contained between 1.5 and 2.2 percent of the hydrogen LFL, and between 0.03 and 0.04 percent of the methane LFL.

The concentration of ammonia is not expected to be near its LFL of 15 percent by volume (Zabetakis 196J). Though validated sampling for ammonia in tank 241-C-103 has $n$ it been conducted, industrial hygiene monitoring during the November and December sarnpling events indicated a maximum ammonia concentration of $200 \mathrm{ppmv}$. This corresponds to 0.13 percent of the LFL for ammonia.

The CGM monitoring data supports the argument that these permanent gases are not present at levels of concern. Since the CGM used during the November and December 1993 sampling events overreacts to the presence of hydrogen by about a factor of 2 (ISC 1991), the hydrogen in the headspace would account for roughly half of the 4 to 7 percent of the LFL response of the CGM.

\subsection{FLAMMABLE ORGANIC VAPORS}

The flammable organic compounds in the headspace of tank 241-C-103 may be classified as being either semivolatile or volatile. The semivolatile organic compounds present in the headspace come primarily from evaporation of the organic liquid waste. The dominant species in the organic liquid, namely TBP, $n-C_{12} \mathrm{H}_{26}, n-\mathrm{C}_{13} \mathrm{H}_{28}$, and $n-\mathrm{C}_{14} \mathrm{H}_{30}$, are all found in the vapor phase. The volatile organic compounds present in the headspace are primarily radiolytic or chemical degradation products of semivolatile and nonvolatile organic waste.

The December 1993 vapor sampling event was performed to quantify the NPH and TBP present in the headspace of tank 241-C-103. Headspace samples were collected using OSHA versatile sampler (OVS) traps, which were lowered through the observation riser (\#7) to an elevation about $0.9 \mathrm{~m}(3 \mathrm{ft})$ above the waste surface. OVS traps contain a prefilter to trap and coalesce any aerosol droplets, and 2 layers of a solid sorbent that adsorb semivolatile organic vapors. Laboratory testing of the OVS traps, including aerosol challenge testing and extraction efficiency testing, as well as analytical quantitation methodology, has been aocumented by Ligotke et al. (1993). A total of 10 OVS trap samples were collected from the headspace, with 1 being sacrificed for a radiolytic assay to allow transport of samples to the laboratory. The design of the OVS traps, sampling equipment, and detailed analyses results are discussed by Ligotke et al. (1994).

NPH quantitation results from the December vapor sampling are summarized in Table 3-1. Uncertainties in the values reported were estimated to be 21 percent by Ligotke et al. (1994), the dominant uncertainty being 20 percent due to analytical quantitation. Total sample volumes for OVS 1, 2, and 3 were about $0.22 \mathrm{~L}$; volumes for OVS 4, 5, and 6 were 
about $0.88 \mathrm{~L}$; and volumes for OVS 8, 9, and 10 were about $4.4 \mathrm{~L}$. Comparison of values in the last column of Table 3-1 suggests the discrepancies between samples are related to the volumes of air sampled. Though no reason for this apparent relationship has been established, it may be due to the specific manner in which NPH was extracted frorn the three sets of OVS traps. These errors are believed to be too small to significantly affect the conclusions of this report.

Table 3-1. NPH Concentrations Measured in OVS Traps from Tank 241-C-103.

\begin{tabular}{ccccccc}
\hline $\begin{array}{c}\text { Sample } \\
\text { number }\end{array}$ & $\begin{array}{c}\mathrm{n}-\mathrm{C}_{11} \mathrm{H}_{24} \\
\mathrm{mg} / \mathrm{L}\end{array}$ & $\begin{array}{c}\mathrm{n}-\mathrm{C}_{12} \mathrm{H}_{26} \\
\mathrm{mg} / \mathrm{L}\end{array}$ & $\begin{array}{c}\mathrm{n}-\mathrm{C}_{13} \mathrm{H}_{28} \\
\mathrm{mg} / \mathrm{L}\end{array}$ & $\begin{array}{c}\mathrm{n}-\mathrm{C}_{14} \mathrm{H}_{30} \\
\mathrm{mg} / \mathrm{L}\end{array}$ & $\begin{array}{c}\mathrm{n}-\mathrm{C}_{15} \mathrm{H}_{32} \\
\mathrm{mg} / \mathrm{L}\end{array}$ & $\begin{array}{c}\mathrm{Total} \mathrm{NPH} \\
\mathrm{mg} / \mathrm{L}\end{array}$ \\
OVS 1 & $<0.07$ & 0.306 & 0.429 & 0.100 & $<0.07$ & 0.835 \\
OVS 2 & $<0.07$ & 0.287 & 0.435 & 0.085 & $<0.07$ & 0.807 \\
OVS 3 & $<0.07$ & 0.247 & 0.336 & 0.076 & $<0.07$ & 0.659 \\
OVS 4 & $<0.02$ & 0.278 & 0.401 & 0.103 & $<0.02$ & 0.782 \\
OVS 5 & $<0.02$ & 0.235 & 0.358 & 0.099 & $<0.02$ & 0.692 \\
OVS 6 & $<0.02$ & 0.215 & 0.349 & 0.058 & $<0.02$ & 0.622 \\
OVS 8 & $<0.003$ & 0.411 & 0.527 & 0.129 & $<0.003$ & 1.067 \\
OVS 9 & $<0.003$ & 0.383 & 0.574 & 0.158 & $<0.003$ & 1.115 \\
OVS 10 & $<0.003$ & 0.349 & 0.578 & 0.140 & $<0.003$ & 1.067 \\
\hline Average & - & 0.301 & 0.443 & 0.105 & - & 0.850 \\
\hline
\end{tabular}

As indicated in Table 3-1, quantities of $n-\mathrm{C}_{11} \mathrm{H}_{24}$ and $n-\mathrm{C}_{15} \mathrm{H}_{32}$ were below limits of detection in all samples. $n-C_{11} H_{24}$, typically present in significant quantities in the PUREX process diluent, has apparently been virtually eliminated by preferential evaporation from the organic waste during 24 years of storage in the tank farm. The very low vapor pressure of $\mathrm{n}-\mathrm{C}_{15} \mathrm{H}_{32}$, and its low concentration in the organic liquid waste, explain its absence at analytical detection levels.

In addition to the 3 dominant NPH species listed in Table 3-1, several other compounds were detected in the samples. These were neither positively identified nor quantitated, but initial screening indicated them to be semivolatile branched alkanes. Though quantitation by species was not attempted, NPH collectively represented about 90 percent of the total ion abundance of the mass spectra (Ligotke et al. 1994). 
The headspace concentration of NPH indicated by averaging results from the 9 samples is $0.85 \mathrm{mg} / \mathrm{L}$, with an uncertainty of $\pm 0.18 \mathrm{mg} / \mathrm{L}$. Given an LFL for NPH of approximately $46 \mathrm{mg} / \mathrm{L}$ (Zabetakis 1965), these results indicate the headspace to be at about $1.8 \pm 0.4$ percent of the LFL for NPH.

TBP was above the analytical detection limit only in OVS 8, 9, and 10. The maximum observed TBP concentration was about $0.05 \mathrm{mg} / \mathrm{L}$, or roughly $4.3 \mathrm{ppmv}$ (Ligotke et al. 1994). At this concentration, TBP does not contribute appreciably to the headspace flammability.

Samples of the liquid organic waste in tank 241-C-103 were also collected during the December 1993 sampling event. Analysis indicates that the predominant components of the organic liquid waste are all semivolatile. The principle components of the organic liquid, listed approximately by increasing vapor pressures, are given in Table 3-2 (Pool et al. 1994).

Table 3-2. Principle Constituents of Organic Liquid Waste in Tank 241-C-103.

\begin{tabular}{lcc}
\hline \multicolumn{1}{c}{ Compound } & $\begin{array}{c}\text { Relative weight } \\
\text { percent }\end{array}$ & $\begin{array}{c}\text { Flashpoint } \\
\left({ }^{\circ} \mathrm{C}\right)\end{array}$ \\
n-dodecane $\left(\mathrm{n}-\mathrm{C}_{12} \mathrm{H}_{26}\right)$ & 3.8 & 71 \\
alkane* & 0.3 & \\
alkane* & 1.5 & 79 \\
n-tridecane $\left(\mathrm{n}-\mathrm{C}_{13} \mathrm{H}_{28}\right)$ & 15.5 & \\
alkane* & 0.6 & \\
alkane* & 1.3 & \\
n-tridecane (n- $\left.\mathrm{C}_{14} \mathrm{H}_{30}\right)$ & 8.1 & \\
alkane* & 1.0 & 132 \\
n-pentadecane (n- $\left.\mathrm{C}_{15} \mathrm{H}_{32}\right)$ & 1.2 & \\
dibutyl butyl phosphonate (DBBP) & 2.6 & 193 \\
tributyl phosphate (TBP) & 64.0 & \\
\hline
\end{tabular}

*Tentatively identified as branched alkanes in the $\mathrm{C}_{12} \mathrm{H}_{26}$ to $\mathrm{C}_{14} \mathrm{H}_{30}$ range.

Liquid sample analyses support the vapor sample analyses; the 3 NPH species that dominate the vapor phase constitute over 80 percent of the non-phosphate species in the liquid phase. The partial pressure of alkanes is significantly reduced by the presence of

${ }^{4}$ Aldrich 1991 
TBP. While flashpoints of the alkanes listed in Table 3-2 range from 71 to $132{ }^{\circ} \mathrm{C}$, the flashpoint of organic liquid waste samples has been estimated to be in the vicinity of $100{ }^{\circ} \mathrm{C}$ (Pool et al. 1994).

The introduction of fresh air to tank 241-C-103, either as dry instrument air or from the atmosphere by natural barometric changes, could reduce the concentration of flammable vapors. However, the breathing and instrument air purge rates are small relative to the headspace volume, so it is reasonable to expect the semivolatile organic vapors in the headspace to be nearly in equilibrium with the floating pool of organic liquid. Consequently, changes in the ventilation configuration, such as venting all 3 tanks of the cascade through tank 241-C-103, would not significantly impact the concentration of semivolatile organic vapors.

Volatile organic compounds are not present in significant quantities in the organic liquid, according to the analysis shown in Table 2. Analyses of SUMMA canister vapor samples have indicated dozens of volatile organic compounds are present at trace quantities in the headspace, but definitive concentrations of these species are as yet unavailable (Einfeld et al. 1992, Einfeld 1994).

The contribution of volatile organic compounds to flammability of the headspace can be estimated from calibrated CGM data collected during the November and December 1993 sampling events. Assuming that the in-tank CGM readings of 7 percent of the LFL are correct, and that the CGM overcompensates for the hydrogen present by a factor of 2 (ISC 1991), and the response of the CGM to the NPH constituents is negligible, then volatile organic compounds would be responsible for 2.8 to 4.0 percent of the LFL as measured by the CGM.

\subsection{FLAMMABLE ORGANIC LIQUID AEROSOL}

Aerosols form in the high-level waste tanks by the same mechanism as clouds form in the atmosphere. Warm, vapor-laden air from near the surface of the waste rises and is cooled below its dewpoint by contact with cool air from near the tank dome or the dome itself. While it may be said with reasonable confidence that an aerosol has existed in tank 241-C-103 in the past, it is not known whether the aerosol was composed of aqueous droplets, organic droplets or both (see Attachment A).

Inspections of this tank on December 2, 14, and 15, 1993 and January 21, 1994 indicated no visible aerosol was present in the headspace. That an aerosol did but presently does not exist in tank 241-C-103 may be due to a variety of effects, including the gradual cooling of the tank waste, reduction of the volatility of the organic layer, or seasonal temperature changes that result in an aerosol during certain times of the year but not at others. Further consideration of an organic aerosol is given here because it cannot be proven yet that an organic aerosol does not exist at other times of the year. Planned sampling events will address this issue. 
Key concepts for understanding the combustion of an aerosol of liquid NPH droplets have been given in Attachment A. Essentially, the fuel available in the aerosol droplet phase must first be vaporized, and this consumes some of the energy of the fuel. Furthermore, droplets larger than about $1 \mu \mathrm{m}$ in diameter are not apt to evaporate completely and thus burn before the rapidly moving flame front passes the droplet. This makes some of the fuel in larger droplets unavailable for flame propagation. These factors tend to increase the minimum concentration of fuel (vapor + aerosol) required for flame propagation in an aerosol-vapor system. Fuel in the aerosol droplet phase is less flammable than in the vapor phase. It is erring on the safe side to apply the calculated LFL for NPH vapor to an NPH aerosol-vapor system.

Estimates of the probable mass concentration of an NPH aerosol in tank 241-C-103 have been performed by Huckaby and Estey (see Attachment A) and Kummerer (1994) and Postma. The former estimated the concentration of the aerosol to be at or less than $1 \mathrm{mg} / \mathrm{L}$ from a report that the waste surface was visible through the aerosol, and from considerations of likely aerosol mass loading. Given an LFL for NPH of about $46 \mathrm{mg} / \mathrm{L}$, this aerosol mass concentration would be about 2.2 percent of the LFL.

Kummerer (1994) and Postma used the MAEROS-2 program (Gelbard 1982) to model the formation and deposition rate of an organic aerosol in the tank. Their simulation predicted a mass concentration of $0.043 \mathrm{mg} / \mathrm{L}$. Allowing for possible errors in the estimation of conditions and properties, a worst-case calculation was run by increasing the aerosol generation rate by a factor of 10 . The maximum aerosol mass concentration for this case was calculated to be $0.22 \mathrm{mg} / \mathrm{L}$. These estimated and estimated maximum aerosol mass concentrations correspond to about 0.1 and 0.5 percent of the LFL for NPH, respectively.

In summary, though no aerosol was observed in the headspace of tank 241-C-103 in December 1993, it is possible that temperature changes promote the existence of an aerosol at other times of the year. If an organic liquid aerosol is produced at other times, calculations indicate that it would not contribute significantly to the flammability of the headspace. 


\subsection{CONCLUSIONS}

Data and evidence have been presented that indicate gases and vapors in the headspace of tank 241-C-103 are well below the LFL. The principle fuels in the headspace are thought to be: hydrogen, present at 1.5 to 2.2 percent of its LFL; the semivolatile NPH vapor, present at 1.4 to 2.2 percent of its LFL; and volatile organic vapors, collectively fresent at 2.6 to 4.0 percent of their LFL. Assuming the independence of these calculated flammability contributions, the flammability of the headspace is estimated to be between 5.5 and 8.4 percent of the LFL of the mixture. This is well within the operational guideline limit of 20 percent of the LFL established by Tank Farm Safety.

Recent inspections of the tank 241-C-103 headspace indicate that no visible aerosol is currently present. In the event that an aerosol is present under marginally different tank conditions, calculations discussed indicate that the mass concentration of NPH in the aerosol droplet phase would not significantly affect the headspace flammability. Given the composition of the organic liquid in tank $241-\mathrm{C}-103$ of Table 3-2, there is little data to support the premise that the vapors will change significantly with time or season.

Further vapor sampling of tank 241-C-103 is being performed to address the issue of vapor toxicity. Analytical data from this sampling will be evaluated to reaffirm current understanding of the headspace flammability and to verify that seasonal changes in the headspace do not significantly alter the conclusions of this document. 
This page intentionally left blank. 


\subsection{REFERENCES}

Aldrich Chemical Company, 1991, Catalog Handbook of Fine Chemicals, Aldrich Chemical Company, Milwaukee, Wisconsin.

Burke, T. M., 1991, "Summary of Evaporation Modeling for Tank 241-C-103," (internal memorandum to R. E. Raymond, April 11), Westinghouse Hanford Company, Richland, Washington.

Carothers, K. G., 1988, "Tank 103-C Transaction History - Post January 1976," (internal memorandum 13331-88-600 to D. A. Dodd, G. L. Dunford, G. N. Hanson, A. W. Lilly and R. E. Van der Cook, September 22), Westinghouse Hanford Company, Richland, Washington.

Crippen, M. D., 1993, Barometric Pressure Variations, WHC-EP-0651, Westinghouse Hanford Company, Richland, Washington.

Crowe, R. D., M. Kummerer and A. K. Postma, 1993, Estimation of Heat Load in Waste Tanks Using Average Vapor Space Temperatures, WHC-EP-0709, Westinghouse Hanford Company, Richland, Washington.

Einfeld, W. and L. Bustard (Sandia National Laboratories, Albuquerque, New Mexico) and R. A. Rasmussen (Oregon Graduate Institute of Science and Technology, Beaverton, Oregon), 1992, Progress Report - Hanford Tank 103C Vapor Analysis: Evaluation of Canister Sampling and Analysis Techniques, report prepared for J. W. Osborne, Westinghouse Hanford Company, Richland, Washington.

Einfeld, W., 1994, letter dated January 20 to J. W. Osborne, WHC, transmitting Sandia National Laboratories review draft contractor report SAND94-0229, R. A. Rasmussen, lead author, Analysis of Headspace Vapor Samples Collected at Hanford Tank C-103, November 1993, Sandia National Laboratories, Albuquerque, New Mexico.

Estey, S. D., 1992, "Flammability Issue Resolution for 241-C.-1 73," (internal memorandum 7K210-92-446 to M. H. Shannon, October 12), Westinglıouse Hanford Company, Richland, Washington.

Gelbard, F., 1982, MAEROS User Manual, NUREG/CR-1391, SAND80-0822, Sandia National Laboratories, Albuquerque, New Mexico.

Garfield, J. S., 1975, Anticipated Natural Air Breathing Rate for Underground Tanks, ARH-CD-256, Atlantic Richfield Hanford Company, Richland, Washington. 
Hanlon, B. M., 1994, Tank Farm Surveillance and Waste Status Summary Report for September 1993, WHC-EP-0182-66, Westinghouse Hanford Company, Richland, Washington.

ISC, 1991, Cross Sensitivity Multipliers for CMX, HMX, MX250 and MX251 Combustible Detectors, March 7, drawing 1703A1287-200, Industrial Scientific Corporation, Oakdale, Pennsylvania.

Kummerer, M., 1994, "Aerosol Analysis for Tank C-103," (internal memorandum 29120MK-94004 to J. L. Huckaby, January 20), Westinghouse Hanford Company, Richland, Washington.

Ligotke, M. W., and T. R. Clauss, G. W. Dennis, S. C. Goheen, J. L. Huckaby and R. B. Lucke, 1993, Aerosol and Vapor Characterization of Tank 241-C-103: Flammability Assessment Sampling System and Method Validation, PNL-8875, Pacific Northwest Laboratory, Richland, Washington.

Ligotke, M. W. and T. R. Clauss, J. S. Fruchter, R. B. Lucke and S. C. Goheen, 1994, Waste Tank Vapor Project - Aerosol and Vapor Characterization of Tank 241-C-103: Data Report for OVS Samples Obtained 12/02/93, Pacific Northwest Laboratory, Richland, Washington.

Pelletier, R. F., 1993, "EPA Draft Report on Estimating Radionuclide Air Emissions from Diffuse and Fugitive Sources," (internal memorandum to Distribution, July 28), U. S. Department of Energy, Washington, D.C.

Pool, K. H. (lead author), 1994, Analysis of Tank 241-C-103 Liquid Samples (Draft), Pacific Northwest Laboratory, Richland, Washington.

Prentice, B. A., 1991, "Organic Analysis of 103-C Tank Samples (Westinghouse Work Order ED1150)," (letter to R. K. Tranbarger, Westinghouse Hanford Company, Richland, Washington, April 11), Pacific Northwest Laboratory, Richland, Washington.

Story, M. S., 1992, Assessment of Waste Tank Vapor Cryogenic Sampling and Analysis, (report prepared for Pacific Northwest Laboratory by Northwest Instrument Systems, Inc., Kennewick, Washington, May 22).

Trent, G. J., 1990, Draft Report: Characterization Study of the Headspace Gases in Tanks 102-C and 103-C, Westinghouse Hanford Company, Richland, Washington.

Ulbricht, W. H. Jr., 1991, Report on 241-C Tank Farm Air Sampling Results of 1989, WHC-SD-WM-RPT-019, Rev. 0, Westinghouse Hanford Company, Richland, Washington. 
van Tuyl, H. H., 1983, Safety of Organic Solvents in Waste Tanks, (letter 083083 to W. V. Baumgartner, Westinghouse Hanford Company, Richland, Washington, August 30, 1983), Pacific Northwest Laboratory, Richland, Washington.

WHC, 1993, Industrial Hygiene Monitoring Reports for: 11/11/93, 11/12/93, 11/15/93 and 11/16/93 (Work Packages 2E-92-1564/W and 2E-93-0128/W); 12/02/93 (Work Package 2E-92-01760/W); 12/14/93 (Work Package 2E-92-01760/2); and 12/15/93 (Work Package 2E-92-01760/2), Westinghouse Hanford Company, Richland, Washington.

Wood, S. A., 1992, Gas Space Analysis for Tank 241-C-109, WHC-SD-WM-ER-183, Rev. 0, Westinghouse Hanford Company, Richland, Washington.

Zabetakis, M. G., 1965, Flammability Characteristics of Combustible Gases and Vapors, U. S. Department of the Interior, Bureau of Mines, Washington, J.C. 
This page intentionally left blank. 


\title{
ATTACHMENT A
}

AN ENGINEERING ASSESSMENT OF THE

AEROSOL AND VAPOR FLAMMABILITY IN 241-C-103

(WHC-SD-WM-ER-181, Rev. 0)

\author{
J. L. Huckaby \\ and \\ S. D. Estey \\ December 1992
}

Tank Waste Technology Applications 
This page intentionally left blank. 


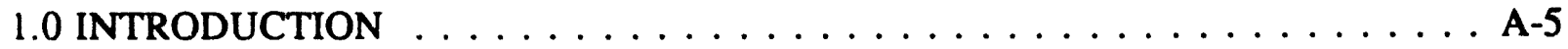

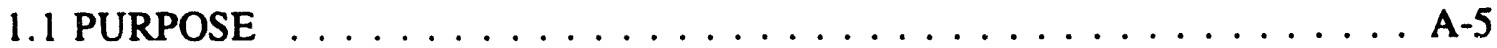

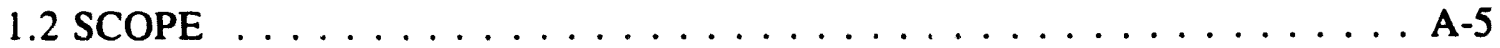

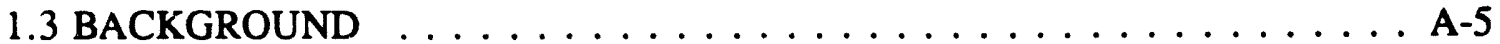

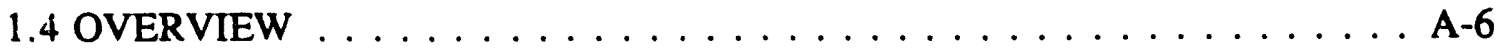

2.0 AEROSOLS $\ldots \ldots \ldots \ldots \ldots \ldots \ldots \ldots \ldots \ldots \ldots \ldots \ldots \ldots$ A-6

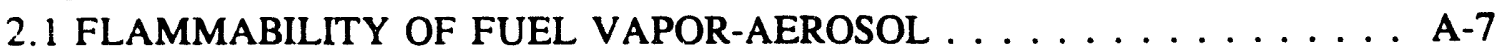

2.2 AEROSOL GENERATION AND DEPLETION MECHANISMS $\ldots \ldots \ldots$ A-8

2.3 TANK CONDITIONS: WEATHER EFFECTS, TEMPERATURES \&

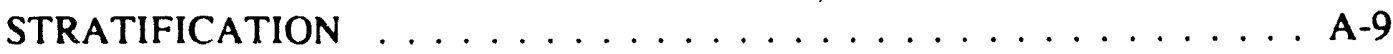

3.0 VAPOR AND GAS CONTRIBUTION TO FLAMMABILITY $\ldots \ldots \ldots \ldots$ A-10

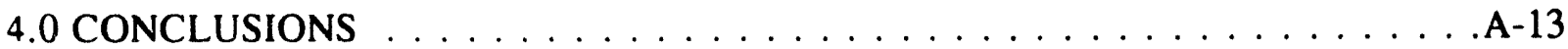

5.0 REFERENCES AND BIBLIOGRAPHY $\ldots \ldots \ldots \ldots \ldots \ldots \ldots$ A $\ldots \ldots$

Appendix A - An Aerosoi Primer $\ldots \ldots \ldots \ldots \ldots \ldots \ldots \ldots \ldots$

Appendix B - Calculation of NPH Partial Pressure $\ldots \ldots \ldots \ldots \ldots \ldots \ldots$ A-17

Appendix C - Calculation of NPH Lower Flammability Limit . . . . . . . . . A-19 
This page intentionally left blank. 


\subsection{INTRODUCTION}

\subsection{PURPOSE}

The purpose of this document is to provide an assessment of the flammability of the headspace in waste tank 241-C-103 based on an understanding of the vapor and aerosol composition. Key to this understanding is evaluation of an aerosol thought to be present, and its contribution to the flammability of the headspace.

\subsection{SCOPE}

Flammability of the headspace aerosol and vapor in tank 103-C is addressed by considering the likely concentration of fuel as vapor and as aerosol droplets. The analysis is restricted to the quiescent tank condition, and does not address flammability issues related to mechanical agitation or pumping operations in the tank. A general discussion of aerosols, their generation, and stability, is given. While much of the discussion is applicable to other Hanford site waste tanks, it is presented as a basis for understanding the headspace of tank 103-C. Principle flammable constituents of tank 103-C are identified and their contribution to the overall flammability of the headspace is proposed.

\subsection{BACKGROUND}

It is currently thought that an organic liquid layer is floating on other wastes in tank 103-C. Direct evidence of this was provided by supernatant liquid samples collected in January, 1991. Two samples were collected from the liquid waste in tank 103-C, one sample taken from the top of the liquid and the second taken from a lower region of the liquid. Lab analysis of the samples revealed that the top sample was an organic liquid, immiscible with the aqueous bottom sample. Analysis of the organic supernate indicated that the major constituents were tributyl phosphate (TBP), which comprised about $70 \%$ of the sample (mass basis), and several alkanes, collectively representing about $30 \%$ of the sample (Prentice 1991).

Carothers (1988) provided a plausible explanation for the origin of such a layer: In the fourth quarter of 1969, a floating layer of organic liquid was observed in tank 102-C and measured to be 10 to 13 inches deep (Anderson 1969). Since tank 102-C had been a receiver of organic wash waste from the PUREX plant, it was thought that the approximately 36,000 gallons of organic liquid was PUREX solvent, a mixture of TBP and normal paraffin hydrocarbons in the $\mathrm{C}_{10} \mathrm{H}_{22}$ to $\mathrm{C}_{15} \mathrm{H}_{32}$ size range (NPH). Tank 102-C is reported by Anderson (1990) as being inactive from the fourth quarter, 1969, until the fourth quarter of 1975, when apparently all pumpable liquids were transferred to tank 103-C. Photographs taken of tank 102-C in 1976 support this. Subsequent transfers of waste into and out of tank 103-C (until it was made inactive in 1979) may not have substantially affected this organic layer since it would be a floating layer. 
Based on a waste surface temperature of $42^{\circ} \mathrm{C}$ and an organic liquid predominantly composed of NPH and TBP, there would be insufficient flammable vapor in the headspace of tank 103-C for it to be flammable (van Tuyl (1983). It has been conjectured, however, that if an organic liquid aerosol exists in the headspace there may actually be enough fuel (vapor + aerosol) to constitute a flammable condition.

Like many of the waste tanks at Hanford, tank 103-C has been observed to have an aerosol in its headspace. Tank farm operators and tank photographic crews report observing a fog in tank 103-C in recent years. Recent photographs, which do not indicate an aerosol to exist, may be misleading; the tank headspace was exhausted to eliminate the fog prior to taking photographs, since photography of the waste surface could not be performed through the fog.

It is possible, given the scenario of a floating layer of organic liquid and the mechanisms for aerosol generation to be discussed below, that an organic liquid aerosol exists. It is also possible that an aqueous aerosol exists, so that aqueous and organic liquid droplets coexist as an aerosol. It is even possible that an aerosol of droplets having both an aqueous and organic phase exists in tank 103-C. The existence of an aqueous aerosol would depend on the thickness of the floating organic, the partial pressure of water of the aqueous supernate, tank dome and wall temperatures and the dynamics of the tank headspace (i.e. convection currents).

\subsection{OVERVIEW}

The principal interest in an aerosol in tank 103-C thus arises from the concern that if an organic liquid aerosol exists, it may result in a flammable fuel-air mixture within the tank. While only representative samples from the headspace of tank 103-C and their accurate analyses can definitively resolve the flammability question, a strong case can be made that the fuel concentration in the headspace of tank 103-C is well below the lower flammability limit (LFL).

Given the current understanding of the situation, it is highly unlikely that a flammable condition does or could exist in tank 103-C. Conservative estimates of the vapor and aerosol place the amount of fuel in the headspace of tank $103-\mathrm{C}$ at less than $8.5 \mathrm{mg} / \mathrm{l}$. Since the lower flammability limit (LFL) for NPH is about $46.9 \mathrm{mg} / \mathrm{l}$ (see Appendix C), it is expected that the concentration of fuel in the headspace of tank 103-C will be significantly below the LFL.

\subsection{AEROSOLS}

A definition of the term "derosol" is given in Appendix A, An Aerosol Primer. This appendix is intended to provide supplemental information on aerosols in general, present some fundamentals with the help of an example, and supply insight into the nature of aerosols in the waste tanks. 


\subsection{FLAMMABILITY OF FUEL VAPOR-AEROSOL}

When a given concentration of fuel in air supports the propagation of a flame, it is said to be flammable. The lower flammability limit (LFL) is that concentration of fuel in air which is just sufficient to support flame propagation. The LFL values of different fuels have historically been determined by experiment. For paraffin hydrocarbons, the constituents of $\mathrm{NPH}$, the LFL is observed to be between about 45 to $50 \mathrm{mg} / 1$ of fuel at $25^{\circ} \mathrm{C}$ (Zabetakis 1965). The LFL for NPH was calculated to be about $46.9 \mathrm{mg} / 1$ at $42^{\circ} \mathrm{C}$, using the experimentally determined LFL values of the principle components in NPH (see Appendices $B$ and $\mathrm{C}$ ).

The LFL value for hydrocarbons can also be calculated by determining the amount of fuel which, when burned, raises the temperature of the flame front (the unburned fuel and air mixture) up to about $1300^{\circ} \mathrm{C}^{\prime}$. If the temperature of the fuel-air mixture is near $1300^{\circ} \mathrm{C}$, it will have a lower $\mathrm{LFL}$, since less heat will be required to raise the reactants to the required $1300^{\circ} \mathrm{C}$ [see Zabetakis (1965) and references therein]. Conversely, if endothermic processes take place as the temperature is raised (e.g. evaporation of liquid aerosol or bulk fuel, or evaporation of a water aerosol), the LFL will be higher, since to reach the burning temperature of $1300^{\circ} \mathrm{C}$, more fuel must be present. This fact tends to make fuel in the form of aerosol droplets slightly less flammable than fuel in the form of vapor ${ }^{2}$.

Flammability experts C. Grelecki, of Hazards Research Corporation, and S. E. Slezak, of Sandia National Laboratories, have been consulted regarding the flammability of an NPH aerosol. Their consensus is that fuel in the form of aerosol droplets having diameters below about $1 \mu \mathrm{m}$ should be treated as though it were in vapor form ${ }^{3}$. Thus if $5.0 \mathrm{mg} / \mathrm{lof} \mathrm{NPH}$ vapor and an additional $0.1 \mathrm{mg} / \mathrm{l}$ of NPH aerosol composed of droplets with diameters less than $1 \mu \mathrm{m}$ were present, then the mixture should be considered to have $5.1 \mathrm{mg} / \mathrm{l}$ of burnable fuel. Essentially, droplets with diameters below about $1 \mu \mathrm{m}$ can be expected to completely evaporate as the flame front moves into them, and they contribute their fuel as vapor.

Droplets having diameters above about $10 \mu \mathrm{m}$ do not contribute significantly to the burnable

'This is the White concept of constant limit flame temperature, discussed briefly by Kuchta (1985), p. 27.

2 Studies indicate that except for certain highly non-volatile solids, virtually all combustion of fuels with oxygen occurs in the gas phase. Thus, when a pool of liquid burns, it is not the liquid itself burning, but the vapor immediately above the liquid. Similarly, it is the vapor from a droplet which burns and not the droplet itself. A discussion of aerosol droplet combustion is given by Hidy (1984).

A number of studies support this experimentally; Burgoyne and Cohen (1954) give a brief review of earlier work. 
fuel of a mixture ${ }^{4}$. There is not sufficient time, as the flame front moves into and past such droplets, to evaporate an appreciable fraction of such large droplets. Large droplets of NPH would be warmed as the flame front heated the reactants, but the actual droplet temperature rise would lag significantly behind that of the gas. While it is conceivable that very large droplets could burn as individual sources of fuel (Burgoyne and Cohen 1954), the significant point here is that they do not contribute to flame propagation. Furthermore, for reasons to be discussed below, large droplets are not expected to be present in significant numbers in the headspace of tank 103-C.

Droplets having diameters between 1 and $10 \mu \mathrm{m}$ are expected to contribute to the available fuel, but to a lesser extent than smaller droplets. The amount of fuel they contribute to flame propagation would depend upon such factors as the vapor pressure of the liquid, the latent heat of vaporization and the burning velocity.

\subsection{AEROSOL GENERATION AND DEPLETION MECHANISMS}

The mechanism by which aerosols form in the waste tanks is the same mechanism by which natural fogs and clouds form: Warm, vapor-laden air is cooled below its dew point temperature ${ }^{5}$. In tank $103-\mathrm{C}$, the air near the liquid surface (surface temperature approximately $42^{\circ} \mathrm{C}$ ) is warmed by the liquid, and becomes nearly saturated with vapors from the liquid. This warm, vapor-laden air rises to the cooler regions near the tank dome and walls. As the warm air mixes with cooler air it becomes supersaturated and forms tiny droplets of liquid. This mixture of gases, vapors and suspended droplets is an aerosol. Convection currents and settling carry the droplets to all regions of the tank vapor space.

Liquid aerosols persist only if a mechanism exists to maintain the generation of new droplets. Droplet collisions and the increased settling velocity of larger droplets result in the depletion of droplets, and unless new droplets are formed the aerosol will only be transitory. In a waste tank, droplet generation, growth, coagulation and settling all occur simultaneously resulting in a range of particle sizes. In the absence of disturbing forces, a steady-state would develop when the competing phenomena of droplet growth and depletion reach a dynamic equilibrium. In a steady-state condition even the size distribution and particle number density would remain approximately constant.

+ This concept, as well as that in the following paragraph, comes from S. E. Slezak and aerosol scientist J. Brockman, also of Sandia National Laboratories.

' This discussion does not address the possibility of generating aerosols within the waste tanks by mechanical means, such as might occur during pumping operations. No other plausible mechanisms exist for aerosol generation in tank 103-C. Tank bumping, as an aerosol generation mechanism, has been studied by others (Ruecker and Anderson 1987) who found that only very dilute aerosols could be formed. 
The aerosol in tank 103-C has been reported as a moderately dense fog; it is obviously present, yet from the riser, operators can still see the surface of the waste (the operators would be looking through approximately 18 feet of fog in the headspace). Given this information and the likely characteristics of a condensation aerosol, it is estimated that the mass of fuel droplets in the aerosol is less than $1 \mathrm{mg} / \mathrm{l}$. This corresponds, for example, to an aerosol of NPH having $10^{6}$ particles per $\mathrm{cm}^{3}$ and a mass median particle diameter of about $1.4 \mu \mathrm{m}$. Placing a conservative one order of magnitude error on the estimated value of 1 $\mathrm{mg} / \mathrm{l}$ would limit the fuel in droplet form to no more than $10 \mathrm{mg} / \mathrm{l}$ in tank $103-\mathrm{C}$.

\subsection{TANK CONDITIONS: WEATHER EFFECTS, TEMPERATURES \& STRATIFICATION}

Fluctuations of barometric pressure, atmospheric temperature and gusts of wind in the tank farms could disturb the steady-state condition of the aerosol within a waste tank, but the extent to which they do is questionable. J. S. Garfield (1975) used the average daily barometric pressure changes observed in calendar year 1973 to determine that the average breathing rate per day for a waste tank was equal to 0.00667 times the headspace volume of the tank. Thus, on average, approximately $0.7 \%$ of the headspace of a tank might be exchanged over a 24 hour period. Even if a ten-fold excursion from this average occurred (amounting to an exchange of $7 \%$ of the headspace volume in 24 hours), little significant change in the aerosol or vapor profile within the headspace would be expected.

Seasonal changes in the temperature of the ground directly above tank $103-\mathrm{C}$ could affect the temperature of the concrete tank dome. Since the mechanism for aerosol generation is based on the difference between the dome and waste surface temperatures, this has potential for affecting the aerosol. Unfortunately there are no operable thermocouples in the upper headspace of tank 103-C and the temperature of the dome itself is unknown, so the effects of seasonally fluctuating dome temperatures is uncertain. It is doubtful, however, that seasonal changes in the dome temperature would substantially affect the aerosol droplet concentration or significantly change the mean droplet diameter.

Despite the lack of specific temperature data on the concrete dome of tank 103-C, it can be said with reasonable assurance that it is cooler than the surface of the waste. This results in an inverted temperature profile, where cooler, denser air is above the warmer, lighter air. This unstable arrangement would result in convection currents continuously circulating air from one region to the other. It therefore seems very unlikely that stratification of vapors or aerosol could occur to any great extent. Thus, as a first approximation, the total fuel concentration at any given level (vapor + aerosol, averaged over a horizontal cross section of the tank) is probably about the same as the total fuel concentration at any other level.

Temperature gradients and convection are expected to affect the partition of fuel as vapor and as aerosol. The aerosol near the waste surface in a rising convection column will be relatively dilute, while the vapor content at the same location is expected to be near its maximum value. As the vapor, aerosol and air mixture rises and cools, the aerosol droplets grow in size and number, but only by as much as the vapor concentration is reduced. Thus, 
the partition of fuel as vapor and as aerosol changes with the local temperature, but the total concentration of fuel should change very little. A cooler, falling convection column may also have a slightly greater mass of fuel per unit volume. This would arise because the cooler air-vapor mixture is denser, however, this density difference would not change the total fuel concentration by more than a few percent.

Yet another consideration is that individual aerosol droplets tend to settle under the influence of gravity. Droplet settling tends to diminish the total fuel concentration (vapor + aerosol) as the height within the tank increases. Thus, the mechanisms which generate a denser aerosol in upper regions of the headspace, convection and cooling, maybe offset to some extent by the fall of individual droplets downward. The effect of droplet settling on the vertical distribution of fuel, however, depends heavily on droplet size. If indeed the aerosol in tank 103-C has a moderate to small average droplet size, say a mass median diameter of less than $2 \mu \mathrm{m}$, droplet settling would probably make the lower levels of the headspace only slightly more fuel-rich ${ }^{6}$.

The point is that while the tank headspace is not homogeneous, the current physical model of the headspace does not allow for substantial fluctuations in the total amount of fuel (vapor + aerosol) per unit volume from region to region. Summarizing the above discussion, based on the proposed physical model and its assumptions, it is estimated that convection has a significant homogenizing effect, horizontal temperature gradients primarily affect only the vapor/aerosol partition, and droplet settling tends to make the lower headspace regions only slightly more fuel-rich.

\subsection{VAPOR AND GAS CONTRIBUTION TO FLAMIMABILITY}

The flammability of gases and vapors in tank 103-C has been addressed in the Program Plan for the Resolution of Tank Vapor Issues (Osborne 1992). It is stated in that program plan that: "NPH is the major contributor to vapor space flammability." Furthermore, it states: "The effect of other organic/flammable gases and vapors on the LFL of 241-C-103 is taken as 50 percent of the flammable level contributed by NPH vapors." And it supports this statement with the comment that "... historical analysis of the tank has shown that the other [non-NPH] flammable species in the vapor space typically do not reach the value of one-third of the total flammable species."

The statement that NPH vapor contributes twice as much to the flammability of the headspace of tank 103-C as all other flammable vapors combined is supported by a variety of vapor sample analyses (e.g. Tranbarger and Kimura [1991]) and consideration of the organic supernate sample analysis (Prentice 1991). It is therefore assumed in this document that the total concentration of fuel vapors in the headspace of tank 103-C may be calculated by determining the concentration of NPH vapor, and then multiplying this concentration by the

6 The terminal settling velocities of spheres increase proportionally to the square of the sphere diameter (Hinds 1982). A $2 \mu$ m diameter droplet of NPH falls at about $0.009 \mathrm{~cm} / \mathrm{s}$. 
factor of 1.5. Other compounds thought to contribute to the vapor phase flammability are acetone, ammonia, 1-butanol, methyl-isobutyl ketone and TBP, in that order (Tranbarger and Kimura (991).

While various methods for determining the vapor pressure of NPH give slightly different results, the value of $0.78 \mathrm{mmHg}$ at $42^{\circ} \mathrm{C}$ (the waste surface temperature in tank 103-C) will be used here. The calculation of this value is described in Appendix B. This vapor pressure is based on Raoult's law, Antoine's equation for individual species, and a species distribution based on an assay of unused NPH reported by Beary (1970). If the original mixture of $70 \%$ NPH and 30\% TBP (volume basis) is assumed, and Raoult's law for the partial pressure of $\mathrm{NPH}$ is applied, then about $5.0 \mathrm{mg} / \mathrm{l}$ of NPH vapor would be present near the waste surface in tank 103-C (see Appendix B). This value would err on the conservative side, since it was assumed that the NPH-TBP ratio is that of the PUREX process, and in fact the preferential evaporation of NPH since the organic waste left the PUREX process has certainly diminished the NPH fraction?.

Multiplying the concentration of NPH vapor by a factor of 1.5 to estimate the total fuel vapor concentration gives an estimated $7.5 \mathrm{mg} / \mathrm{l}$ of flammable vapor in the headspace. This is about $16 \%$ of the fuel concentration needed to reach the calculated $46.9 \mathrm{mg} / \mathrm{l} \mathrm{LFL}$ value for NPH. The conclusion drawn is that of Kirch (1983), van Tuyl (1983), and Borsheim and Kirch (1991); namely that the vapors in tank 103-C do not constitute a flammable condition.

A noteworthy point is that the solvent extraction in the PUREX process was normally run with a $70 \%$ NPH, 30\% TBP solution, while the 1991 analysis of the organic supernate indicated just the opposite relationship of about 30\% NPH and 70\% TBP (Prentice 1991). This inconsistency is probably best explained by reports that tank $103-\mathrm{C}$ was actively exhausted at various times for periods of about 2 weeks to 3 months in the 1980's. During these periods the preferential evaporation of NPH could result in a loss of NPH commensurate with the concentration observed in the 1991 organic liquid assay $^{8}$. If the supernate assay is correct, then the amount of lighter, more volatile components of NPH, which dominate its vapor pressure, would be greatly diminished. Furthermore, since the mole fraction of NPH would have been decreased relative to TBP, its partial pressure above the supernate would be similarly decreased. These considerations lend credence to the statement that the $5.0 \mathrm{mg} / \mathrm{I} \mathrm{NPH}$ vapor, calculated on the basis of the original NPH mixture and NPH-TBP ratio, is a conservatively high value.

'Furthermore, the more volatile components of NPH would be removed preferentially. The table in Appendix C attributes $20 \%$ of the vapor pressure of unused NPH to decane, while recent analysis of the vapor identified no decane at all (Tranbarger and Kimura 1991).

${ }^{8}$ Kirch (1983) and Van Tuyl (1983) have both calculated evaporation rates for NPH in waste tanks. 


\subsection{CONCLUSIONS}

This document describes the current understanding of the flammability of an aerosol and vapors in tank 103-C. A mechanism by which an aerosol of NPH and TBP is generated and maintained in this waste tank has been suggested, and its contribution to the airborne fuel in the tank estimated. Consideration has been given to the likely character of the aerosol, and it was concluded that the amount of fuel in aerosol droplet form is probably $1 \mathrm{mg} / 1$ or less. The partial pressure of NPH in tank $103-\mathrm{C}$ was estimated to be $5.0 \mathrm{mg} / \mathrm{l}$, this value being based on the very conservative assumptions that the NPH has its original distribution of components, and that it still represents $70 \%$ by volume of the organic supernate. Fuel in vapor form was estimated to be approximately $7.5 \mathrm{mg} / \mathrm{l}$, based on the total fuel vapor being 1.5 times the fuel as NPH vapor. The resulting total fuel concentration, thought to be a conservative estimate, is $8.5 \mathrm{mg} / \mathrm{l}$. This value is about $18 \%$ of the LFL. Using the very conservative value of $10 \mathrm{mg} / \mathrm{l}$ of fuel present as an aerosol and the above assumptions, it is estimated that no more than $17.5 \mathrm{mg} / \mathrm{l}$ of fuel could be expected in the headspace of tank 103-C. This would represent less than $40 \%$ of the LFL. 


\subsection{REFERENCES AND BIBLIOGRAPHY}

Anderson, J. D., 1990, A History of the 200 Area Tank Farms, WHC-MR-0132, Westinghouse Hanford Company, Richland, Washington.

Anderson, T. D., 1969, Organics in 102-C Tank, (internal letter to W. L. Godfrey, dated October 2), Westinghouse Hanford Company, Richland, Washington.

Beary, M. M., 1970, Solvent Improvement Resulting from the Use of NPH in the Hanford PUREX Plant, ARH-SA-73, Atlantic Richfield Hanford Company, Richland, Washington.

Borsheim, G. L., and N. W. Kirch, 1991, Summary of Single-Shell Tank Waste Stability, WHC-EP-0347, Westinghouse Hanford Company, Richland, Washington.

Burgoyne, J. H., and L. Cohen, 1954, "The Effect of Drop Size on Flame Propagation in Liquid Aerosols," Roy. Soc. Proc., (London), Vol. 225, pp. 375-392.

Carothers, K. G., 1988, Tank 103-C Transaction History - Post January 1976, (internal memorandum to D. A. Dodd, G. L. Dunford, G. N. Hanson, A. W. Lilly, and R. E. Van der Cook, September 22), Westinghouse Hanford Company, Richland, Washington.

Dean, J. A., editor, 1985, Lange's Handbook of Chemistry, 13th edition, McGraw-Hill Book Company, New York, New York.

Garfield, J. S., 1975, Anticipated Natural Air Breathing Rate for Underground Tanks, ARH-CD-256, Atlantic Richfield Hanford Company, Richland, Washington.

Hinds, W. C., 1992, Aerosol Technology / Properties, Behavior, and Measurement of Airborne Particles, John Wiley \& Sons, New York, New York.

Hidy, G. M., 1984, Aerosols / An Industrial and Environmental Science, Academic Press, Inc., New York, New York.

Huckaby, J. L., 1986, Absorption of Sulfur Dioxide by Growing and Evaporating Water Droplets, Master's Thesis, University of Kentucky, Lexington, Kentucky.

Kirch, N. W., 1983, PUREX Organic Waste, WHC-SD-WM-TI-076, Westinghouse Hanford Company, Richland, Washington.

Kuchta, J. M., 1985, Investigation of Fire and Explosion Accidents in the Chemical, Mining, and Fuel-Related Industries - A Manual, Bulletin 680, Bureau of Mines, United States Department of the Interior, Washington, D.C. 
Moore, J. D., and R. L. Walser, editors, 1980, PUREX Technical Manual, RHO-MA-116, Rockwell International, Rockwell Hanford Operations, Richland, Washington.

Osborne, J. W., 1992, Program Plan for the Resolution of Tank Vapor Issues, WHC-EP-0562, Westinghouse Hanford Company, Richland, Washington.

Prentice, B. A., 1991, Organic Analysis of 241-C-103 Tank Waste, (letter to R. K. Tranbarger, Westinghouse Hanford Company, April 11), Pacific Northwest Laboratory, Richland, Washington.

Ruecker, C. M., and C. M. Anderson, 1987, Aerosol Concentrations Resulting from Sparging Air Through Various Solutions, (final letter report prepared for the U.S. Department of Energy and Westinghouse Hanford Company), Pacific Northwest Laboratory, Richland, Washington.

Tranbarger, R. K., and R. T. Kimura, 1991, Activated Carbon Filtration of Organic and Ammonia Vapors from Underground Single-Shell Tanks, Waste Characterization and Assay - Theory and Practice, American Nuclear Society, LaGrange, Illinois.

van Tuyl, H. H., 1983, Safety of Organic Solvents in Waste Tanks, (letter to W. V. Baumgartner, Westinghouse Hanford Company, August 30), Northwest Laboratories, Richland, Washington.

Zabetakis, M. G., 1965, Flammability Characteristics of Combustible Gases and Vapors, Bulletin 627, Bureau of Mines, United States Department of the Interior, Washington, D.C. 


\section{Appendix A - An Aerosol Primer (by J. L. Huckaby)}

The term aerosol refers to a collection of suspended solid or liquid particles in a gas. Fogs, smogs, clouds, smoke, and fumes are all aerosols. Household aerosol spray cans generate an aerosol of whatever liquid is in the can; the compressed gas that forces the liquid out is not an aerosol.

Generally, an aerosol consists of solid and/or liquid particles having diameters in the $100 \mu \mathrm{m}$ to $0.01 \mu \mathrm{m}$ range. In terms of more common objects, coarse human hair is about $100 \mu \mathrm{m}$ thick, soap bubble films are about $1 \mu \mathrm{m}$ thick, smaller cigarette smoke particles are about 0.1 $\mu \mathrm{m}$ in diameter, and a typical virus has a diameter of about $0.01 \mu \mathrm{m}$ (Hinds 1982). Particles with diameters of less than about $0.1 \mu \mathrm{m}$ are easily suspended and their motion tends to be controlled by diffusion (i.e. Brownian motion) (Hinds 1982). For larger particles, having diameters between about 0.1 and $1 \mu \mathrm{m}$, the effects of diffusion and gravitational settling are both important to particle motion. Still larger particles, with diameters greater than about 1 $\mu \mathrm{m}$, tend to be more strongly influenced by gravitational settling than by diffusion.

An important property of aerosols is that they have large surface area per unit volume of the particulate phase. This allows a maximum of interface between the condensed phase and the vapor phase, and promotes rapid establishment of vapor-liquid equilibrium. While a small puddle of water can set for hours in a room with $50 \%$ relative humidity, the same amount of water sprayed into the room as an aerosol of $1 \mu \mathrm{m}$ droplets would evaporate in less than 1 second. The large surface area per unit volume of condensed phase also enhances the ability of a liquid aerosol to scrub soluble vapors from the ambient gas. Furthermore, for most practical purposes (a notable exception being a moving flame front) there are no thermal or concentration gradients within individual liquid droplets to impede the establishment of gas phase-droplet phase equilibrium (Huckaby 1986).

One property of aerosols that is relevant here is that they scatter visible light. This makes an aerosol visible to the naked eye even though the individual aerosol droplets may be too small to be visible. Aerosols of clear liquids, such as water and NPH, appear white in white light, and attenuate the light passing through them. This means that if a non-trivial aerosol is present in a waste tank, it will be visible (given light in the headspace). Furthermore, if a waste tank aerosol appears diffuse (as opposed to thick or milky), it has a relatively low number of droplets per unit volume, and a correspondingly low mass per unit volume. The appearance of an aerosol as a very dense fog does not, however, imply that it contains a great deal of mass in the droplet phase. Very thick, milky fogs can occur as a result of a large number of very small droplets per unit volume, and yet they actually have a relatively low amount of mass in droplet form.

Aerosols can be generated by subdivision of bulk material (e.g. fine wood dust or atomized liquids from spray cans) or by condensation of vapor in a supersaturated gas. In the waste tanks the mechanism is condensation. An example of a condensation aerosol occurs when you take a hot shower: Air becomes warmed and virtually saturated with water vapor in the shower and rises. A fog or mist begins to form near the ceiling since contact with the 
ceiling cools the warm vapor-laden air below its dew point temperature. Settling mist evaporates as it falls, eventually saturating lower regions with water vapor. Since the mist can not evaporate in vapor-saturated air, the layer of fog along the ceiling appears to get thicker as the mist falls further and further before evaporating. Eventually, if the shower is left on, the entire room will be filled with a fog.

Technically, the condensation of a supersaturated vapor to form an aerosol particle can occur via homogeneous or heterogeneous nucleation. Homogeneous nucleation requires very specialized conditions and is not a significant mechanism in the waste tanks. Heterogeneous nucleation involves the condensation of vapor on fine particles or ions already present in the gas. Airborne dust particles introduced to a fog-producing waste tank serve as sites for the condensation of vapor, and are eventually "rained out" of the air space as the fog droplets grow and fall. This process is so effective it is the basis of certain ultra-clean room technologies. Waste tanks which have fogs in their headspaces are consequently not apt to have significant amounts of suspended radioactive dusts.

In principle the dynamic generation of fog droplets in the waste tanks via heterogeneous nucleation would eventually remove all dust and ions from the tank air space and leave no sites for further heterogeneous nucleation. This does not occur, however, since the ionizing radiation within the tanks generates an ample supply of ions from air molecules to serve as nucleation sites and maintain the process. (These ions are called "light ions" or "gaseous ions" and should not be confused with the metal and transuranic ions in the solid and liquid tank wastes.)

Condensation aerosols in a nuclei-rich environment, such as the headspace of tank 103-C, typically have small average particle diameters. As the droplet size in an aerosol decreases, settling and coagulation eiffects decrease, making it possible to have more droplets per unit volume. However, a very dense aerosol having the relatively small average droplet diameter (e.g. $0.3 \mu \mathrm{m}$ ) will have much less droplet phase mass per unit volume than a relatively diffuse aerosol with a much larger $(e . g .3 \mu \mathrm{m})$ average droplet diameter.

An aerosol having $10 \mathrm{mg} / \mathrm{l}$ of liquid in the droplet phase would be considered to be a very concentrated aerosol ${ }^{9}$. While it is certainly possible to generate aerosols having densities greater than $10 \mathrm{mg} / \mathrm{l}$, special conditions would be required to sustain them. To give this some perspective, typical atmospheric fogs have a mass concentration of about $0.01 \mathrm{mg} / \mathrm{l}$ (Hinds 1982).

${ }^{4}$ From conversations with other aerosol scientists, particularly M. W. Ligotke of Pacific Northwest Laboratories. 


\section{Appendix B - Calculatico of NPH Partial Pressure}

1. Vapor Pressure of Pure NPH

The vapor pressure of pure NPH, P $\mathrm{NPH}$, was calculated by combining Rauolt's law and Dalton's law:

$$
p_{\mathrm{NPH}}=\Sigma \mathrm{x}_{\mathrm{i}} \mathrm{p}_{\mathrm{i}} \text {. }
$$

Here $x_{i}$ and $p_{i}$ are the iquid phase mole fraction and vapor pressure of component $i$, respectively. The vapor pressures of the individual components were determined using Antoine's equation,

$$
\log _{10} p_{i}=A-B /(t+C)
$$

where $t$ is the temperature in Celsius, and $\mathrm{A}, \mathrm{B}$ and $\mathrm{C}$ are constants. The following table gives the individual components of NPH, their molecular weights, Antoine constants, vapor pressures (evaluated at $42^{\circ} \mathrm{C}$ ), and their weight fractions in the liquid phase:

\begin{tabular}{lcccccccc}
\hline Component & & $\begin{array}{c}\mathrm{MW}_{\mathrm{i}} \\
(\mathrm{g} / \mathrm{mol})\end{array}$ & $\mathrm{A}^{10}$ & $\mathrm{~B}$ & $\mathrm{C}$ & $\begin{array}{c}\mathrm{p}_{\mathrm{i}} \\
(\mathrm{mmHg})\end{array}$ & $\begin{array}{c}\mathrm{w}_{\mathrm{i}}{ }^{11} \\
(\%)\end{array}$ & $\mathbf{x}_{\mathrm{i}}$ \\
\hline Decane & $\mathrm{C}_{10} \mathrm{H}_{22}$ & 142.3 & 6.94365 & 1495.17 & 193.86 & 4.022 & 3.2 & 0.039 \\
Undecane & $\mathrm{C}_{11} \mathrm{H}_{24}$ & 156.3 & 6.97220 & 1569.57 & 187.70 & 1.377 & 29.9 & 0.328 \\
Dodecane & $\mathrm{C}_{12} \mathrm{H}_{26}$ & 170.3 & 6.99795 & 1639.27 & 181.84 & 0.472 & 28.4 & 0.286 \\
Tridecane & $\mathrm{C}_{13} \mathrm{H}_{28}$ & 184.4 & 7.00756 & 1690.67 & 174.22 & 0.154 & 23.6 & 0.219 \\
Tetradecane & $\mathrm{C}_{14} \mathrm{H}_{30}$ & 198.4 & 7.01300 & 1740.88 & 167.72 & 0.052 & 14.9 & 0.129 \\
\hline
\end{tabular}

Here the liquid phase mole fraction of each component was calculated from the liquid phase weight fraction:

where

$$
\mathbf{x}_{1}=\mathrm{a}_{\mathrm{i}} / \mathrm{\Sigma a}_{\mathrm{i}}
$$

$$
\mathrm{a}_{\mathrm{i}}=\mathrm{w}_{\mathrm{i}} / \mathbf{M W _ { \mathrm { i } }} \text {. }
$$

10 These Antoine constants are from Lange's Handbook of Chemistry (Dean 1985). The vapor pressure data on which these values are based were taken at elevated temperatures, and the application of these constants at $42^{\circ} \mathrm{C}$ is an extrapolation of that data, using Antoine's equation.

$"$ These weight fractions are for unused NPH, from Beary (1970). Note that this particular batch of NPH contains no $n-\mathrm{C}_{15} \mathrm{H}_{32}$. 
Raoult's law thus gives a total vapor pressure of $\mathrm{p}_{\mathrm{NPH}}=0.784 \mathrm{mmHg} .2$. Partial pressure of NPH over $70 \%$ NPH, 30\% TBP (by volume) solution

To obtain the liquid phase mole fractions of TBP and NPH, the volume fractions of these components were first converted to mole fractions. The following table is based on data from Moore and Walser (1980):

\begin{tabular}{lcc}
\hline & TBP & NPH \\
\hline Density, $\rho(\mathrm{g} / \mathrm{ml})$ & 0.975 & 0.76 \\
Volume fraction, $v$ & 0.30 & 0.70 \\
Molecular weight, $\mathrm{MW}(\mathrm{g} / \mathrm{mol})$ & 266.3 & $171.5^{12}$ \\
\hline
\end{tabular}

The liquid phase mole fractions, $x_{i}$, were calculated using the formula

where

$$
\mathrm{x}_{\mathrm{i}}=\mathrm{b}_{\mathrm{i}} / \Sigma \mathrm{b}_{\mathrm{i}}
$$

$$
b_{i}=v_{i} \rho_{i} / M W_{i} \text {. }
$$

The results are $\mathrm{x}_{\mathrm{NPH}}=0.739$ and $\mathrm{x}_{\mathrm{THP}}=0.261$.

Raoult's law for the partial pressure of NPH above the solution, using the value of $\mathrm{p}_{\mathrm{NPH}}=$ $0.784 \mathrm{mmHg}$ obtained in the previous section, is

$$
(0.784 \mathrm{mmHg})(0.739)=0.579 \mathrm{mmHg} \text {. }
$$

Application of the ideal gas law, using the average molecular weight of NPH and a temperature of $42^{\circ} \mathrm{C}$, gives a mass concentration of $5.05 \mathrm{mg} / \mathrm{l}$ of $\mathrm{NPH}$.

${ }^{12}$ This molecular weight for NPH is the average molecular weight, weighted by individual mole fractions, from the previous section of this appendix. 


\section{Appendix C - Calculation of NPH Lower Flammability Limit}

Zabetakis (1965) has stated that for most paraffinic hydrocarbons materials the LFL at $25^{\circ} \mathrm{C}$ is 45 to $50 \mathrm{mg} / \mathrm{l}$. In this appendix the LFL of NPH is calculated using data from the following table:

\begin{tabular}{ccccc}
\hline Component & $\begin{array}{c}\mathrm{LFL}_{i}{ }^{13} \\
(\mathrm{mg} / \mathrm{l})\end{array}$ & $\mathrm{x}_{\mathrm{i}}$ & $\begin{array}{c}\mathrm{p}_{\mathrm{i}} \\
(\mathrm{mmHg})\end{array}$ & $\mathrm{y}_{\mathrm{i}}$ \\
\hline $\mathrm{n}-\mathrm{C}_{10} \mathrm{H}_{22}$ & 48 & 0.039 & 4.022 & 0.200 \\
$\mathrm{n}-\mathrm{C}_{11} \mathrm{H}_{24}$ & 48 & 0.328 & 1.377 & 0.576 \\
$\mathrm{n}-\mathrm{C}_{12} \mathrm{H}_{26}$ & 46 & 0.286 & 0.472 & 0.172 \\
$\mathrm{n}-\mathrm{C}_{13} \mathrm{H}_{28}$ & 46 & 0.219 & 0.154 & 0.043 \\
$\mathrm{n}-\mathrm{C}_{14} \mathrm{H}_{30}$ & 44 & 0.129 & 0.052 & 0.009 \\
\hline
\end{tabular}

Here the liquid phase mole fraction, $x_{i}$, and component vapor pressure, $p_{i}$, values are those of Appendix B, and the vapor phase mole fraction, $y_{i}$, has been calculated using Raoult's law in the following manner:

$$
y_{i}=x_{i} p_{i} / \Sigma x_{i} p_{i}
$$

Le Chatelier's law, which relates the LFL of a mixture to the component LFL values, can now be applied. The applicable form is

$$
\mathrm{LFL}_{\mathrm{NPH}}=1 / \Sigma\left(\mathrm{y}_{\mathrm{i}} / \mathrm{LFL}_{\mathrm{i}}\right)
$$

This formula gives $\mathrm{LFL}_{\mathrm{NPH}}=47.5 \mathrm{mg} / 1$, at $25^{\circ} \mathrm{C}$. The $\mathrm{LFL}$ decreases with increasing temperature. The highest temperature expected in the headspace of tank 103-C would be at the waste surface, thought to be about $42^{\circ} \mathrm{C}$. A correction of the LFL to this temperature is made using a formula from Zabetakis (1965) for alkanes:

$$
\mathrm{LFL}_{\mathrm{T}}=\mathrm{LFL}_{25}\left[1-0.000784\left(\mathrm{~T}-25^{\circ}\right)\right]
$$

For $42^{\circ} \mathrm{C}$, the $\mathrm{LFL}$ for $\mathrm{NPH}$ is about $46.9 \mathrm{mg} / \mathrm{l}$.

${ }^{13}$ These values come from Zabetakis (1965). 
This page intentionally left blank. 


\section{DISTRIBUTION}

\section{Number of copies}

\section{OFFSITE}

U.S. Department of Energy

Trevion II, EM-362

19901 Germantown Road

Germantown, MD 20874-1290

John C. Tseng (3)

Charles O'Dell

Ken Lang

1

U.S. Department of Energy

1000 Independence Ave SW

EM-35

Washington, D.C. 20585

M. Corn

4

Charles S. Abrams

1987 Virginia

Idaho Falls, ID 83404

David O. Campbell

102 Windham Road

Oak Ridge, TN 37830

Fred N. Carlson

6965 North 5th West

Idaho Falls, ID 83401

Donald T. Oakley

555 Quince Orchard Road

Gaithersburg, MD 20878

1

Air Products and Chemicals

7201 Hamilton Blvd

Allentown, PA 18195-1501

George E. Schmauch 


\title{
DISTRIBUTION (continued)
}

\author{
OFFSITE \\ 1 \\ Ames Laboratory \\ Room 107, Spedding Hall \\ Ames, IA 50011 \\ G. Junk, c/o M. Forsling \\ 1 \\ Harvard School of Public Health \\ 665 Huntington Ave \\ Bldg 1, Rm G-1 \\ Boston, MA 02115 \\ Melvin W. First \\ 1 \\ Hazards Research Corporation \\ 200 Valley Road, Suite 301 \\ Mt. Arlington, NJ 07856 \\ Chester Grelecki \\ 1 \\ Lawrence Livermore National Laboratory \\ P.O. Box 808, L-221 \\ Livermore, CA 94550 \\ Billy C. Hudson \\ 1 \\ MIT/Dept of Nuclear Eng. \\ 77 Massachusetts Ave. \\ Room 24-102 \\ Cambridge, MA 02193 \\ Mujid S. Kazimi
}


DISTRIBUTION (continued)

\section{OFFSITE}

Northwest Instrument Systems, Inc.

3100 George Washington Way

Richland, WA 99352

Michael S. Story

1

Oak Ridge National Laboratory

P. O. Box 2008

MS-6495

Oak Ridge, TN 37831

Charles W. Forsberg

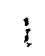

Oak Ridge National Laboratory

Analytical Chemistry Division

P.O. Box 2008

Oak Ridge, TN 37831

Roger A. Jenkins

1

Sandia National Laboratory

P.O. Box 5800

Division 6415

Albuquerque, NM 87185

Scott E. Slezak

2

Sandia National Laboratory

Building 823

1515 Eubank S.E.

Albuquerque, NM 87123

L. Bustard

W. Einfeld 


\section{DISTRIBUTION (continued)}

\section{OFFSITE}

Science Applications International Corporation

12850 Middlebrook Road

Trevion I, Suite 300

Germantown, MD 20874

Ray S. Daniels (3)

\section{ONSITE}

10

U.S. Department of Energy, Richland Field Office

R. F. Christensen (8)

A4-02

R. E. Gerton

A4-02

Public Reading Room

A $1-65$

9

Pacific Northwest Laboratory

R. M. Bean

P8-08

T. W. Clauss

P8-08

J. S. Fruchter

K6-96

S. C. Goheen

P8-08

B. M. Johnson

K1-78

M. W. Ligotke

P7-54

R. B. Lucke

P8-08

K. H. Pool

P8-44

PNL Technical Files

K1-11

47

Westinghouse Hanford Company

W. T. Alumkal

R2-52

H. Babad

R2-78

M. L. Bell

T6-16

G. L. Borsheim

R2-11

D. A. Bragg

R $1-49$

R. B. Conrad

H5-09

C. DeFigh-Price (3)

B4-55

J. G. Flandro

R2-31

J. C. Fulton

R2-31 


\section{DISTRIBUTION (continued)}

\section{ONSITE}

Westinghouse Hanford Company (continued)

J. M. Grigsby

H5-32

B. D. Groth

B4-08

H. D. Harmon

R2-52

J. L. Huckaby (10)

R2-78

R. A. Huckfeldt

R3-54

M. N. Islam (3)

R3-08

N. W. Kirch

R2-11

M. J. Klem

R2-07

C. A. Kuhlman

B3-30

M. Kummerer

H4-62

J. L. Lee

R2-36

R. F. Meisinger

E6-31

D. J. Newland

R2-36

J. W. Osborne

R2-78

R. S. Popielarczyk

R1-30

A. K. Postma

H4-62

D. A. Reynolds

R2-11

D. A. Turner

R2-78

Document Processing and

Distribution (2)

L8-15

Central Files

L8-04

Information Release Administration (3)

A2-24

TFIC

R1-20 

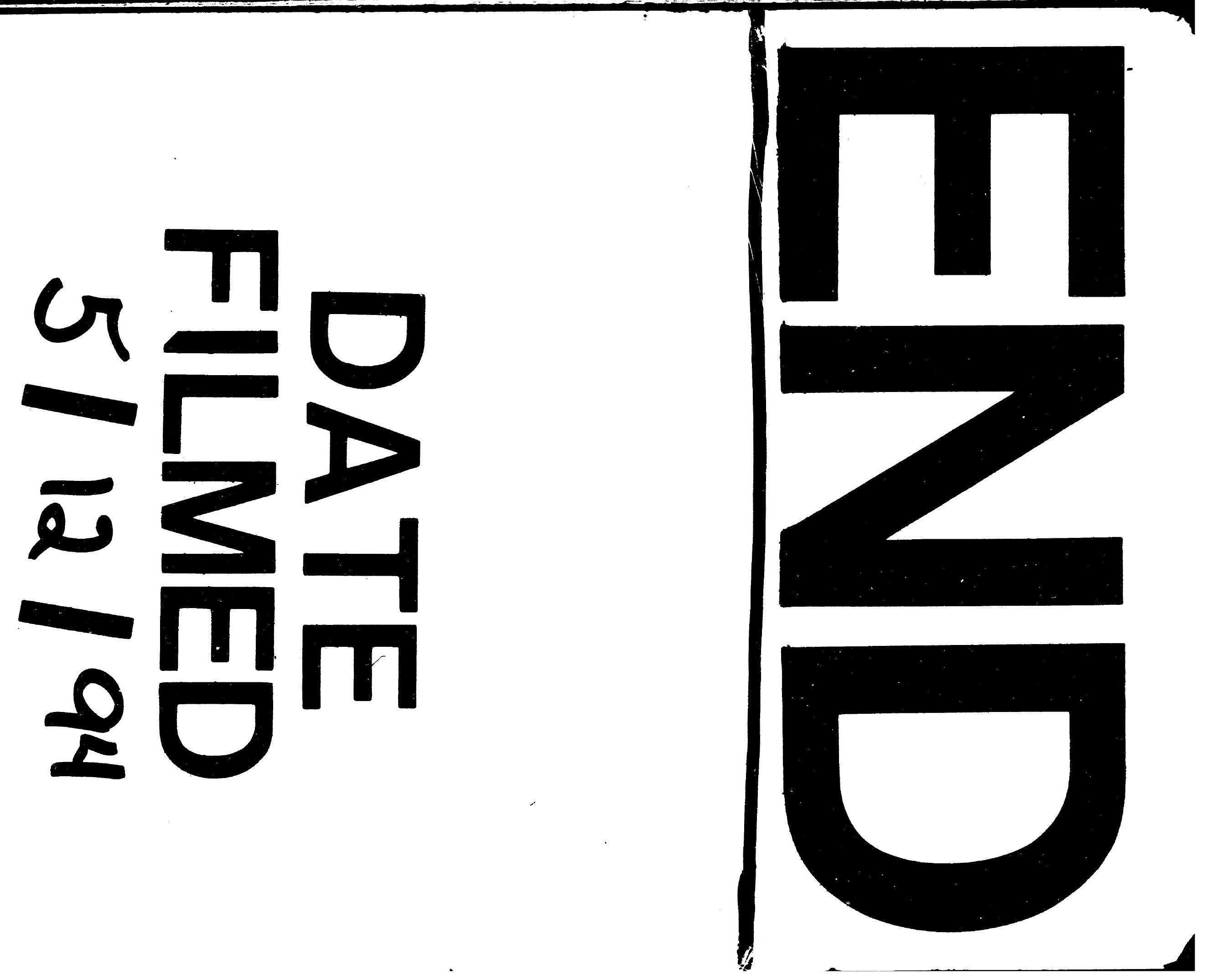


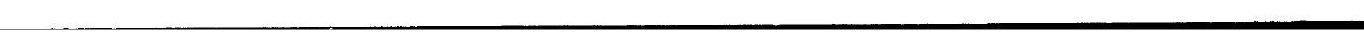

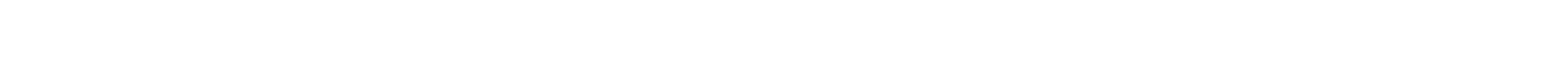

